\title{
Effect of feeding total mixed ration blocks on productive performance of crossbred dairy cattle
}

\author{
Lasna Sahib, Pramod S, Bibin Becha B and Thirupathy Venkatachalapathy $R$
}

Received: 18 April 2020 / Accepted: 23 July 2020 / Published online: 27 October 2020

(C) Indian Dairy Association (India) 2020

\begin{abstract}
A feeding trial of four weeks was conducted using forty crossbred dairy cattle reared under intensive system. The animals were divided into 2 groups, based on milk yield, parity and stage of lactation and fed either a commercially available total mixed ration (TMR) blocks or conventionally available compounded cattle feed (in form of pellet) and green grass separately at different times of the day. The results indicated that the total daily milk yield was significantly lower $(p<0.01)$ in the group fed TMR blocks when compared to the group fed conventionally. Feeding TMR blocks or conventional feeding with compounded cattle feed did not have any significant effect on the milk composition viz fat, solids not fat (SNF), lactose and protein content. The results suggested that feeding TMR blocks showed negative impact on milk production when compared to conventional feeding system with compounded cattle feed.
\end{abstract}

Keywords: Crossbred dairy cattle, Conventional feeding, Milk yield, Milk composition, Total mixed ration

Livestock Research Station, Kerala Veterinary and Animal Sciences University, Thiruvazhamkunnu- 678 601, Kerala India

Lasna Sahib ( $\square)$

Livestock Research Station, Thiruvazhamkunnu - 678 601, Palakkad, Kerala,

Mob: +91 9495133891, E-mail: lasna@kvasu.ac.in
The common practice usually followed in our country to feed dairy cows is to offer them with concentrates and roughages separately. To meet the high nutritional demands during early and mid lactation, large quantities of concentrates are fed at the expense of high-fiber forages leading to intermittent drops in ruminal $\mathrm{pH}$. As per the current guidelines, the risk of sub-acute ruminal acidosis increases when ruminal $\mathrm{pH}$ drops below 5.6 for more than $3 \mathrm{~h} / \mathrm{d}$ (Plaizier et al. 2008) or below 5.8 for more than 5 to $6 \mathrm{~h} / \mathrm{d}$ (Zebeli et al. 2008). Hence, feeding the animals in the form of total mixed ration (TMR) aids in alleviating such problems and helps to maintain a constant ruminal $\mathrm{pH}$ and thus leading to a better ruminal environment. There are variable reports on impact of feeding TMR on milk production and its composition. Some researchers (Bargo et al. 2002; Kishore et al. 2013; Ferland et al. 2018; Sarker et al. 2019) observed enhanced productivity upon feeding of TMR whereas others indicated that milk production or its composition were not influenced (Hundal et al. 2004; Khan et al. 2010; Kumar et al. 2015; Saikia et al. 2015). Also, currently many commercial TMR blocks are available in the market with unspecified nutritional quality and studies on its influence on the productivity of the crossbred dairy cattle when compared to conventional feeding system are scanty. Hence, the present study was conducted to explore the effect of feeding a commercial total mixed ration (TMR) block $v$ s. conventional feeding system on milk yield and its composition in crossbred dairy cattle.

Forty crossbred dairy cattle were divided into two groups of twenty each based on milk yield, parity and days in lactation and were assigned randomly to one of the two feeding systems. One of the groups (TMR group) was fed with TMR blocks based on hay (procured from Kerala Feeds Ltd., Kerala) along with $5 \mathrm{~kg}$ green grass whereas the control group (conventionally fed group) was fed with concentrate feed (compounded cattle feed in form of pellets manufactured at feed plant under Department of Animal Nutrition, Kerala Veterinary and Animal Sciences, University) and roughages separately. The TMR blocks (as per manufacturer's recommendations) and concentrates (as per Package of Practices Recommendations 2016, Kerala Veterinary and Animal Sciences University), as per the animals' requirement based on milk yield were offered to the respective groups before morning and afternoon milking and orts were recorded after 24 hour consumption. The control group was fed with $25 \mathrm{~kg}$ of 
Table 1 Proximate composition (\% on DM basis) of feed stuffs

\begin{tabular}{llll}
\hline & Total mixed Ration Block & Compounded cattle feed & Green grass \\
\hline Crude protein & 14.86 & 18.53 & 5.68 \\
Crude fibre & 15.93 & 5.62 & 35.44 \\
Ether extract & 2.18 & 2.2 & 2.00 \\
Total ash & 11.48 & 13.5 & 6.44 \\
Nitrogen free extract & 43.85 & 53.12 & 44.23 \\
Calcium & 1.00 & 1.20 & 0.50 \\
Phosphorus & 0.58 & 1.04 & 0.28 \\
\hline
\end{tabular}

Table 2 Effect of feeding TMR on milk production and milk composition

\begin{tabular}{lcc}
\hline Parameter & Control group & TMR group \\
\hline DM Intake (kg/day)** & $11.21^{\mathrm{a}} \pm 0.20$ & $12.46^{\mathrm{b}} \pm 0.29$ \\
Milk yield (kg/day) & & \\
First day of trial & $10.45 \pm 0.48$ & $10.25 \pm 0.52$ \\
Week I* & $10.40^{\mathrm{a}} \pm 0.18$ & $9.86^{\mathrm{b}} \pm 0.19$ \\
Week II $^{* *}$ & $10.36^{\mathrm{a}} \pm 0.17$ & $9.43^{\mathrm{b}} \pm 0.19$ \\
Week III** $^{* *}$ & $9.04^{\mathrm{b}} \pm 0.16$ \\
Week IV** & $10.09^{\mathrm{a}} \pm 0.18$ & $8.90^{\mathrm{b}} \pm 0.17$ \\
Milk composition (\%) on $15^{\text {th }}$ day of trial & $9.84^{\mathrm{a}} \pm 0.19$ & \\
Fat & $3.38 \pm 0.19$ & $3.40 \pm 0.14$ \\
SNF & $7.96 \pm 0.08$ & $7.87 \pm 0.08$ \\
Protein & $3.13 \pm 0.03$ & $3.10 \pm 0.03$ \\
Lactose & $4.21 \pm 0.05$ & $4.16 \pm 0.04$ \\
Milk composition (\%) on 22 & \\
Fat & & \\
SNF & $3.18 \pm 0.10$ & $3.23 \pm 0.12$ \\
Protein & $8.02 \pm 0.09$ & $7.86 \pm 0.07$ \\
Lactose & $3.13 \pm 0.03$ & $3.09 \pm 0.03$ \\
\hline
\end{tabular}

*Means bearing different superscripts in the same row differ significantly $(p<0.05)$

**Means bearing different superscripts in the same row differ significantly $(\mathrm{p}<0.01)$

green grass (Napier hybrid and Guinea grass) separately in three offerings. The animals were provided clean and fresh water ad libitum. All the animals were maintained under uniform managemental conditions. The TMR block, compounded cattle feed and grass was analyzed at Animal Feed Analytical and Quality Assurance Laboratory, Namakkal (AOAC, 2012). Ca and P estimation was done as per AOAC 927.02 and 965.17 , respectively.

Daily milk yield was recorded and composition of milk was determined at weekly intervals using Ekomilk Ultra pro milk analyzer (Milkana KAM 98-2A). The data was analysed using MS Excel 2007 and 'Independent sample T test' was used for comparing the means.

Proximate composition of the TMR block and compounded cattle feed used in the study are presented in Table 1. The nutrient composition of the TMR blocks used in the study complies with the nutrient specifications for TMR for lactating cattle as mentioned by Kishore et al. (2017). Daily dry matter intake (DMI) of the animals in both the group is provided in the Table 2. DMI was significantly higher in TMR group when compared to the control group. Similar results have been reported by Sarker et al. (2019) who could also observe a significant improvement in DMI in Red Chittagong cows when feed was offered as TMR blocks when compared to the conventional feeding system. In contrary to this, Hundal et al. (2004) and Kumar et al. (2015) concluded that feeding system does have any significant effect on daily dry matter intake.

The average milk yield on the first day of the trial and average daily milk yield on weekly basis are presented in Table 2 . The milk yield was significantly lower in the TMR group when compared to the control group during all the four weeks of the study. The results were not in accordance with the observations of the researchers who either reported a significant improvement in milk production upon feeding TMR (Bargo et al. 2002; Kishore et al. 2013; Ferland et al. 2018; Sarker et al. 2019) or of those who couldn't observe any significant impact on milk production on feeding TMR (Hundal et al. 2004; Khan et al. 2010; Kumar et al. 2015; Saikia et al. 2015). In the present study, both TMR and 
compounded cattle feed were procured from two different sources and hence the constituent ingredients might be different which would have resulted in lower milk production in TMR group when compared to control group, though both the groups were fed in congruence with their requirements. The reduction in milk production in the TMR group might also be due to the fact that the animals in the present study were accustomed only to green grass as the roughage source and hence the change in the roughage source may have reduced the milk production.

The effect of feeding TMR on milk composition has been shown in table 2. No significant difference could be observed in milk composition viz fat, solids not fat (SNF), protein and lactose content in both the groups either on $15^{\text {th }}$ day or on $22^{\text {nd }}$ day of the trial. The results were in confirmation with those of Saikia and Saikia (2015) who could not observe any effect of different feeding systems on milk constituents. Similarly, Khan et al. (2010) and Hundal et al. (2004) reported that milk constituents except lactose were not influenced by different feeding systems. However, Bargo et al. (2002) and Sarker et al. (2019) reported an increase in fat, protein and SNF per cent with TMR feeding.

\section{Conclusion}

Hence, from the present study it could be concluded that lower milk production was observed due to feeding of commercially purchased TMR blocks when compared to conventional feeding system.

\section{References}

AOAC, (2012). Official methods of analysis, Association of official analytical chemist $19^{\text {th }}$ edition, Washington DC, USA

Bargo F, Muller LD, Delahoy JE, Cassidy TW (2002) Performance of high producing dairy cows with three different feeding systems combining pasture and total mixed rations. J Dairy Sci 85: 29482963
Ferland MC, Guesthier MA, Cue RI, Lacroix R, Burgos SA, Lefebvre D, Wade KM (2018) Effect of feeding system and grain source on lactation characteristics and milk components in dairy cattle. J Dairy Sci 101: 8574-8585

Hundal JS, Gupta RP, Wadhwa M, Bakshi MPS (2004) Effect of feeding total mixed ration on the productive performance of dairy cattle. Anim Nutr Feed Technol 04: 179-186

Khan SR, Singh SK, Mudgal V (2010) Effect of feeding complete rations on the performance of lactating crossbred cows. Indian J Anim Nutr 27: 261-264

Kishore KR, Kumar DS, Ramana JV, Rao ER (2013) Field trial of maize stover based complete ration vis-à-vis conventional ration on lactation performance in graded Murrah buffaloes. Anim Sci Reporter 7: $123-127$

Kishore KR, Kumar DS, Rao ER (2017) Prospects of total mixed ration (TMR) feeding in livestock production. B Environ Pharmacology Life Sci 6: 90-95

Kumar V, Tyagi A, Thakur SS, Singh NP (2015) Effect of different feeding systems on performance of lactating Murrah buffaloes. Indian J Dairy Sci 68: 61-64

Plaizier JC, Krause DO, Gozho GN, McBride BW (2008) Subacute ruminal acidosis in dairy cows. The physiological causes, incidences and consequences. Vet J 176: 21-31

Saikia N, Saikia BN (2015) Effect of feeding total mixed ration (TMR) on milk constituents in lactating cows. Indian J Anim Prod Manag 31: 97-98

Saikia N, Saikia BN, Das AK (2015) Performance of lactating cows on total mixed ration (TMR). Environ Ecol 33: 64-67

Sarker NR, Yeasmin D, Habib MA, Tabassum F (2019) Feeding effect of total mixed ration on milk yield, nutrient intake, digestibility and rumen environment in Red Chittagong Cows. Asian J Med Biol Res 5: 71-77

Zebeli Q, Dijkstra J, Tafaj M, Steingass H, Ametaj B, Drochner W (2008). Modelling the adequacy of dietary fibre in dairy cows based on the response of ruminal $\mathrm{pH}$ and milk fat production to composition of the diet. J Dairy Sci 91: 2046-2066 